\title{
Characterization of an IS-like element from Mycobacterium tuberculosis
}

\author{
Francesca Mariani, ${ }^{1}$ Enza Piccolella, ${ }^{2}$ Vittorio Colizzi, ${ }^{1}$ Rino Rappuoli ${ }^{3}$ \\ and ROY GROSs ${ }^{4 *}$ \\ ${ }^{1}$ Dipartimento di Biologia, Università di Roma 'Tor Vergata', Italy \\ ${ }^{2}$ Dipartimento di Biologia Cellulare, I. Università di Roma 'La Sapienza', and Università 'La Tuscia', Viterbo, Italy \\ ${ }^{3}$ IRIS, Via Fiorentina 1, 53100 Siena, Italy \\ ${ }^{4}$ Lehrstuhl für Mikrobiologie, Theodor-Boveri-Institut für Biowissenschaften (Biozentrum) der Universität Würzburg, \\ 8700 Würzburg, Germany
}

(Received 24 February 1993; revised 19 April 1993; accepted 22 April 1993)

\begin{abstract}
A DNA sequence, present in members of the Mycobacterium tuberculosis complex, has been identified and characterized. The distribution of this DNA sequence among mycobacterial species was analysed by DNA hybridization and PCR experiments. As the sequence was detected only in bacteria belonging to the $M$. tuberculosis complex, it may be useful for the rapid discrimination of mycobacteria. Interestingly, the sequence has some characteristics of an insertion element (IS) and codes for a hypothetical protein with significant homologies to proteins encoded by several IS elements of other organisms, namely IS427 and IS869 from Agrobacterium tumefaciens, IS402 from Pseudomonas cepacia, Tn4811 from Streptomyces lividans and ISRm4 from Rhizobium meliloti. Together, these elements form a previously unrecognized family of transposable elements. This finding suggests the possibility of horizontal gene transfer between pathogenic mycobacteria and other organisms including Gram-negative plant-pathogenic bacteria.
\end{abstract}

\section{Introduction}

During the recent genetic analysis of several mycobacterial species, various repetitive DNA elements have been found; many of them have features in common with typical IS elements (Cirillo et al., 1991; Eisenach et al., 1990; Green et al., 1989; Kunze et al., 1991; Martin et al., 1990; McAdam et al., 1990; Moss et al., 1992; Patel et al., 1990; Thierry et al., 1990; Woods \& Cole, 1990). Transposable elements can be of value as genetic tools. For example, in many other pathogens, insertion mutants have contributed substantially to our understanding of the respective virulence mechanisms. Furthermore, there exist many reports which demonstrate the value of repetitive elements for epidemiological and diagnostic purposes, as the presence or number and distribution of these elements in the bacterial genome can be specific for a species or even for strains within a species (Rappuoli \& Gross, 1990). The use of mycobacterial transposable

*Author for correspondence. Tel. 931888 4403; fax 9318884402.

The nucleotide sequence data reported in this paper have been submitted to EMBL and have been assigned the accession number $\mathrm{X} 65618$. elements and repetitive DNA sequences for diagnostic and epidemiologial purposes has already been established by several groups (Clark-Curtiss \& Docherty, 1991; Eisenach et al., 1990; Grosskinsky et al., 1989; McFadden et al., 1987; Patel et al., 1990; van Embden et al., 1993).

Here, we report on the identification of a DNA sequence that appears to be specific for species of the Mycobacterium tuberculosis complex, including the vaccine strain $M$. bovis BCG. Interestingly, the sequence has similarities with IS elements of other organisms such as Agrobacterium tumefaciens, Rhizobium meliloti, Pseudomonas cepacia and Streptomyces lividans. Together these elements form a novel family of insertion elements. This finding raises the question of the possibility of horizontal gene transfer between pathogens of plants and mammals.

\section{Methods}

Mycobacterial strains. Table 1 (Results) shows the mycobacterial isolates used in this study.

DNA manipulations. Mycobacterial DNA was isolated as recently described (Vismara et al., 1990). All other DNA manipulations and DNA sequencing were carried out according to standard procedures (Maniatis et al., 1982). For cloning and sequencing experiments the vector pBluescript (Stratagene) was used. Oligonucleotide primers for 
sequencing were synthesized on a 380A DNA synthesizer (Applied Biosystems).

DNA probes and hybridization experiments. Radioactive labelling of a 451 bp Pst / BamHI restriction fragment containing about half of the IS-like element was carried out using a random priming kit (GibcoBRL). Hybridization experiments were carried out under stringent conditions as previously described (Vismara et al., 1990). Briefly, hybridization was carried out at $65^{\circ} \mathrm{C}$ in $5 \times \mathrm{SSC}$ buffer overnight. Then the filter was washed three times for $30 \mathrm{~min}$ at $65^{\circ} \mathrm{C}$ in a buffer containing $0 \cdot 1 \times \mathrm{SSC}$ and $0 \cdot 1 \%$ SDS.

PCR techniques. The oligodeoxyribonucleotide primers with the sequence 5'-GTGGTCGAGCCGTTGATGCCG-3' and 5'AGCCGCGTTCGACGGTGTTGC-3' specific for the coding region of the mycobacterial ORF at sequence positions 101-121 and 831-851, respectively, were used in PCR amplification experiments. Amplification was performed in $0.5 \mathrm{ml}$ microfuge tubes (Perkin-Elmer) in a final volume of $50 \mu \mathrm{l}$. The reaction mixture contained $10 \mathrm{mM}-\mathrm{Tris} / \mathrm{HCl}$ (pH 8.3), $50 \mathrm{~mm}-\mathrm{KCl}, 1.5 \mathrm{~mm}-\mathrm{MgCl}_{2}, 50 \mu \mathrm{M}-\mathrm{dNTP}, 0.1 \mu \mathrm{M}$-primer, $100 \mathrm{ng}$ chromosomal DNA and $1.25 \mathrm{U}$ Taq polymerase (Promega). The reaction was performed using an automated Thermal Cycler (Perkin-Elmer). The samples were amplified in 30 cycles consisting of denaturation at $94^{\circ} \mathrm{C}$ for $1 \mathrm{~min}$, annealing of primers at $65^{\circ} \mathrm{C}$ for $1 \mathrm{~min}$ and primer extension at $72^{\circ} \mathrm{C}$ for $1 \mathrm{~min}$.

Computer analysis. Sequence data were analysed with the GCG package run on a VAX/VMS computer (Devereux et al., 1984). The TFASTA and PILEUP programs were used under standard conditions for database searching and alignment of predicted protein sequences.

\section{Results and Discussion}

\section{Features of the nucleotide sequence}

During the molecular characterization of clones from a $\lambda$ gt11 library of $M$. tuberculosis, part of an open reading frame (ORF) coding for a hypothetical protein with sequence homologies to proteins of known IS elements was identified (see below). The entire ORF was cloned by screening a $M$. tuberculosis library in $\lambda 2001$ (Vismara $e t$ al., 1990) using the cloned EcoRI fragment of the $\lambda \mathrm{gt} 11$ library containing the ORF as a hybridization probe. The sequence analysis revealed that the complete ORF is located on a $2.1 \mathrm{~kb} P s t \mathrm{I} / E c o R I$ fragment. The ORF shows a codon usage which is similar to other mycobacterial genes sequenced so far (data not shown) and comprises $924 \mathrm{bp}$, corresponding to a coding capacity of 308 amino acids (Fig. 1). A putative Shine-Dalgarno sequence is present, which is nearly identical to that of the $65 \mathrm{kDa}$ heat shock protein of $M$. tuberculosis (data not shown), but no obvious transcriptional signals can be found. The further analysis of the nucleotide sequence revealed some interesting features such as long inverted repeats in front of the ORF and at its $3^{\prime}$-end. These repeated sequences are $17 \mathrm{bp}$ in length and contain only a single mismatch (Fig. 1). The inverted repeats are flanked by short $4 \mathrm{bp}$ direct repeats with the sequence 5'-CTAG-3' (Fig. 1). The presence of such a structure, long inverted repeats flanked by direct repeats, is a typical feature of many insertion elements.
Comparison of the mycobacterial sequence with the sequences of other IS elements

Using the TFASTA program (Devereux et al., 1984), a homology search in databases was performed, which revealed interesting homologies of the putative mycobacterial protein to proteins from IS427 and IS 869 of $A$. tumefaciens, to IS402 of $P$. cepacia, to Tn4811 of $S$. lividans and to ISRm4 of $R$. meliloti (Chen et al., 1992; De Meirsman et al., 1990; Ferrante \& Lessie, 1991; Paulus et al., 1991; Soto et al., 1992). Fig. 2 shows the alignment of the various polypeptides and demonstrates that the $\mathrm{N}$-terminal part of the mycobacterial protein shows several regions of similarity in its amino acid sequence to the proteins encoded by the ORFs 3 and 4 of IS 869 and IS427, respectively, to one ORF of IS402, to ORF 3 of Tn 4811 and to the unique ORF of IS $R m 4$. Interestingly, the C-terminal part of the mycobacterial protein has significant homologies to ORF1 of IS869, the second ORF of IS402 and ORFx of IS427. Apparently, two different proteins encoded by the elements IS 869 , IS402 and IS427 are unified into one protein in the case of $M$. tuberculosis.

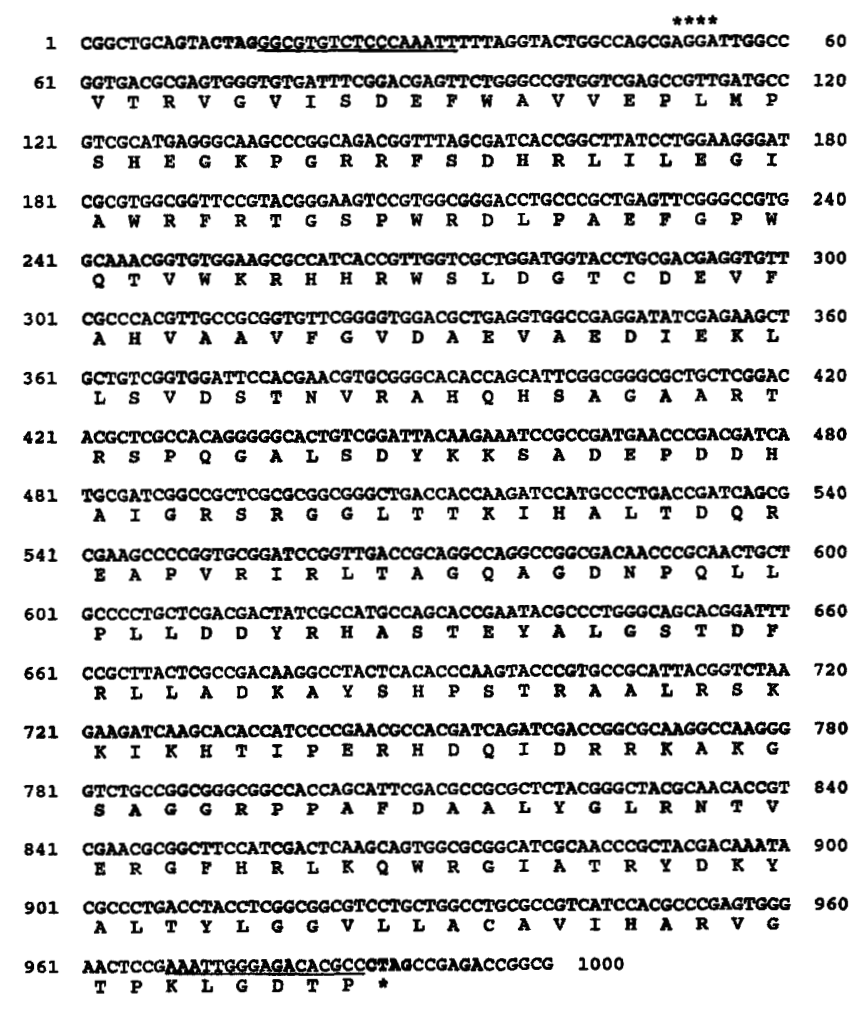

Fig. 1. General organization of the putative IS element found in $M$. tuberculosis H37RV. Below the nucleotide sequence, the amino acid sequence of the 308-amino-acid protein is shown starting with a GTG codon close to a possible Shine-Dalgarno sequence (marked by asterisks, ${ }^{*}$ ). The inverted repeats at the termini of the element are underlined and the duplicated host sequence is in bold. 


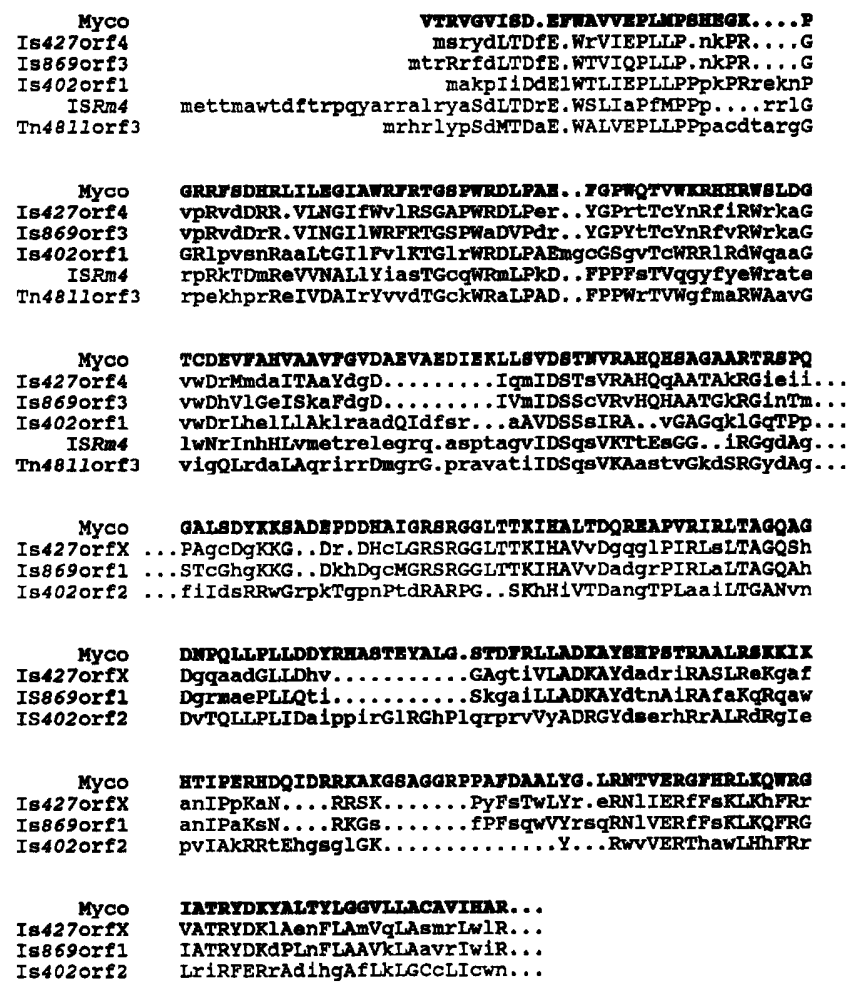

Fig. 2. Alignment of the amino acid sequences of proteins encoded by IS402, IS427, IS $869, \operatorname{Tn} 4811$ and ISRm4 homologous to the mycobacterial protein. On the top, the mycobacterial sequence is shown in bold. According to the sequence from the GenEMBL database, ORFx of IS427 does not contain a start codon; obviously this ORF has lost its function in the sequenced copy of IS427. Capitalized letters symbolize sequence similarity or identity with the mycobacterial sequence. Homologous amino acids were grouped as follows: I, L, V, M; F, Y, W; H, K, R; E, D, N, Q; A, G, S, T, P; C.

Further comparison of the four sequences revealed some other common features such as inverted repeats at the ends of the elements. Moreover, comparison of the insertion point flanking regions revealed in all cases a small duplication of a host sequence, which in several cases has an interesting similarity, as the dinucleotide $5^{\prime}-\mathrm{TA}-3^{\prime}$ can be found in the centre of this sequence (De Meirsman et al., 1990; Ferrante \& Lessie, 1991; Paulus et al., 1991; Scordilis et al., 1987; Vanderleyden et al., 1986).

Therefore, it was tempting to speculate that we have identified an IS-like element, which should have a length of $968 \mathrm{bp}$ and may have caused a duplication of four base pairs during its insertion. Interestingly, the putative element does not itself contain a stop codon for the 308amino-acid ORF. Instead, the duplicated host sequence 5'-CTAG-3' at the putative insertion point provides the translational stop signal.

\section{Detection of the sequence in mycobacterial species}

In most cases, IS elements are found in several copies on bacterial chromosomes. In order to determine whether the mycobacterial sequence is also present several times on the chromosome, we performed hybridization experiments with a labelled probe comprising about half of the sequence up to the internal BamHI site in the element and BamHI-digested chromosomal DNA of $M$. tuberculosis H37RV, $M$. tuberculosis Johnston and $M$. bovis BCG. Surprisingly, as shown in Fig. 3, only a single hybridizing band could be detected. As this band has the same molecular mass in all three strains, it is likely that the position of the sequence is the same in the three genomes. It is therefore possible that the mycobacterial sequence is of IS origin with site-specific integration, or it may be defective. So far, we have been unable to demonstrate transposition of the mycobacterial sequence (data not shown). As there are no obvious transcriptional signals in front of the ORF, it might be that expression of the ORF and therefore the transposition characteristics of the putative element depend on the transcription

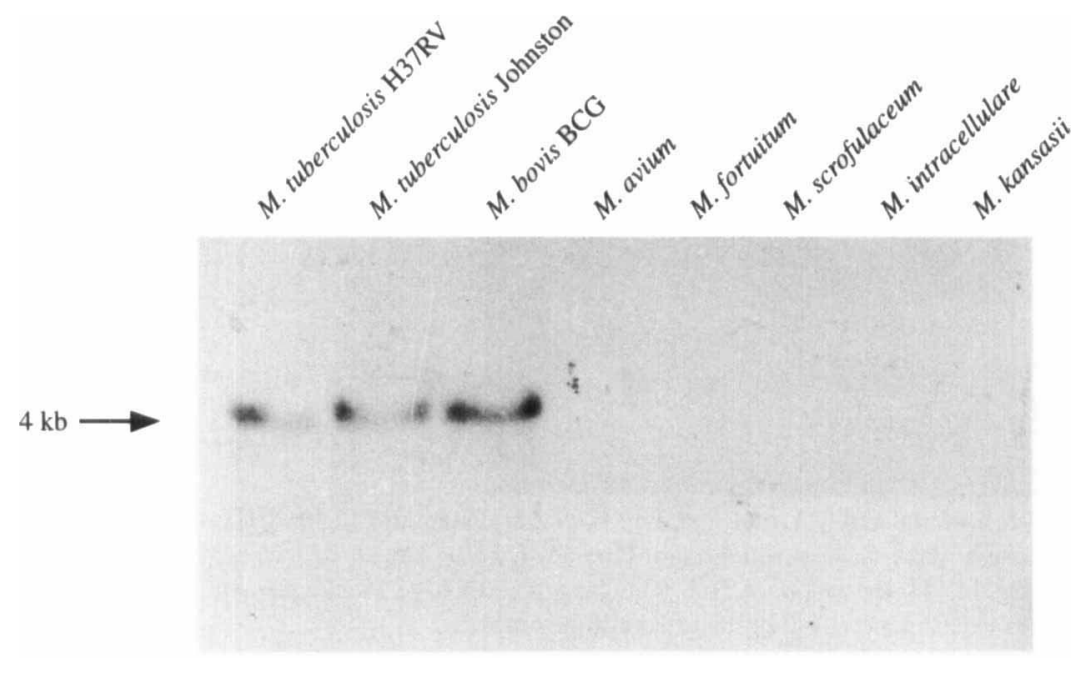

Fig. 3. Southern blot analysis of BamHI digests of chromosomal DNA of various mycobacterial species. A labelled probe containing about half of the mycobacterial IS-like element up to its internal BamHI site was used for hybridization. 
of genes located nearby at the insertion point. It is also possible that the fusion of the two genes present in the functional IS elements into one ORF in $M$. tuberculosis has caused the inactivation of the respective gene product(s), which are likely to be involved in transposition of the element. On the other hand, several other cases are known in which only a single IS copy is present, e.g. IS 1 in Klebsiella aerogenes, IS 2 in $E$. coli B, IS 30 in E. coli C (Iida et al., 1983), and IS6110/IS986 in some strains of M. bovis BCG and M. tuberculosis (Cave et al., 1991).

Several IS and transposable elements have been described in various mycobacterial species, e.g. IS 900 , IS901, IS902, IS1096, IS6110, TN610 and others (Cave et al., 1991; Cirillo et al., 1991; Green et al., 1989; Kunze et al., 1991; Martin et al., 1990; McAdam et al., 1990; Moss et al., 1992; Thierry et al., 1990). By computer analysis, no homology between them and the sequence described here could be found, at either the DNA or protein level. Accordingly, a Southern blot analysis with a probe internal to the gene and PCR amplifications with primers specific for the IS-like element did not reveal the presence of any similar sequence in other mycobacterial species. For this analysis, we chose several species belonging to each of the four Runyon groups (Runyon, 1959) (see Table 1). In Southern hybridization experiments, a signal could be detected only in the $M$. tuberculosis strains and in M. bovis BCG (Fig. 3). As shown in Fig. 4, similar results were obtained with the PCR amplification technique. A PCR product of the predicted size appeared only in the case of $M$. tuberculosis, but not in DNA preparations of the other species (Table 1). This indicates that the sequence is specific for the members of the $M$. tuberculosis complex.
Table 1. Distribution of the IS-like sequence in mycobacterial species according to Southern hybridizations and/or PCR amplification

\begin{tabular}{|c|c|c|}
\hline & Species* & $\begin{array}{l}\text { Presence of } \\
\text { the IS-like } \\
\text { sequence }\end{array}$ \\
\hline \multirow{2}{*}{$\begin{array}{l}\text { M. tuberculosis } \\
\text { complex }\end{array}$} & M. tuberculosis H37RV ${ }^{a}$ & + \\
\hline & $\begin{array}{l}\text { M. tuberculosis Johnston }{ }^{a} \\
M . \text { bovis } B C G^{c}\end{array}$ & $\begin{array}{l}+ \\
+\end{array}$ \\
\hline Runyon I & $\begin{array}{l}M . \text { kansasii }^{a} \\
M . \text { simiae }^{b}\end{array}$ & $\begin{array}{l}- \\
-\end{array}$ \\
\hline Runyon II & $\begin{array}{l}M . \text { scrofulaceum } \\
\text { M. szulgai } \\
\end{array}$ & $\begin{array}{l}- \\
-\end{array}$ \\
\hline Runyon III & $\begin{array}{l}M . \text { avium }^{a} \\
M . \text { intracellulare }^{a} \\
M . \text { terrae }^{b}\end{array}$ & $\begin{array}{l}- \\
-\end{array}$ \\
\hline Runyon IV & $\begin{array}{l}M . \text { fortuitum }^{a} \\
M . \text { phlei } \\
M . \text { smegmatis ATCC } 607\end{array}$ & $\begin{array}{l}- \\
-\end{array}$ \\
\hline
\end{tabular}

* Source: $a$, Vismara et al. (1990); $b$, Culture Collection, University of Rome, Italy; $c$, vaccine strain Sclavo, S.p.A., Siena, Italy.

Therefore, the PCR primers described in this study may be useful for the rapid discrimination of $M$. tuberculosis and $M$. bovis from atypical mycobacteria of the four major Runyon groups.

\section{Evolutionary considerations}

How could these IS-like sequences spread among organisms of genera which are evolutionarily very distant from each other? According to the results of the

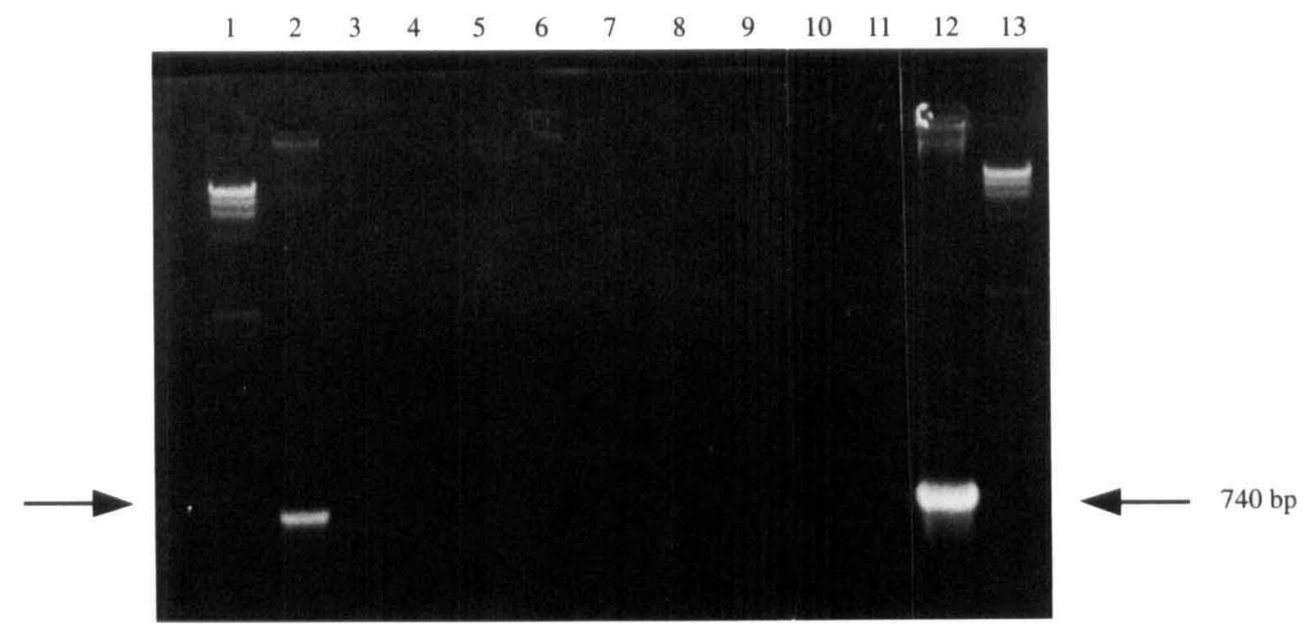

Fig. 4. PCR analysis with primers specific for the mycobacterial ORF. Lanes 1 and 13, DNA size standard ( $\lambda$ HindIII); lane $2, M$. tuberculosis H37RV; lane 3, $M$. kansasii; lane 4, M. avium; lane 5, $M$. scrofulaceum; lane 6, $M$. phlei; lane 7, $M$. terrae; lane 8, $M$. simiae; lane 9, M. szulgai; lane 10, M. fortuitum; lane 11, M. smegmatis ATCC 607; lane 12, DNA of IS-like element cloned in pBluescript. According to the primer pair used for this experiment, a 740 bp band should be amplified. 
hybridization and PCR experiments, bacteria of mycobacterial species that are found in the environment do not contain the sequence here described, and therefore cannot have been the carrier. However, one can speculate that Pseudomonas cepacia, believed to be very actively involved in horizontal exchange of genetic information, may have played a role. Several broad host range plasmids are found in this species, on one of which IS402 was originally identified (Ferrante \& Lessie, 1991; Kuehn et al., 1992; Scordilis et al., 1987). Indeed, conjugational transfer of broad host range plasmids from Gramnegative bacteria into a mycobacterial species was recently demonstrated (Gormley \& Davies, 1991). As $P$. cepacia strains are associated with plant and human disease, especially pulmonary disorders, this organism would have had the opportunity to come into close contact with both the mammalian pathogens in the lung of humans and the environmental organisms. It is possible that an exchange of genetic material between mycobacterial species and other genera has occurred several times as there exists another example of an IS-like element, IS900 of $M$. paratuberculosis, which might be reminiscent of such a horizontal gene transfer event (Green et al., 1989; Hoover et al., 1992).

The authors would like to thank Stefano Ricci for the synthesis of oligonucleotides and B. Aricò, M. Pizza, A. Covacci and M. Domenighini for their permanent interest and for many discussions. Furthermore, we thank D. Vismara for the gift of chromosomal DNA from various mycobacterial species and W. Goebel, J. Hacker and J. Kreft for critical reading of the manuscript. In addition, we would like to thank T. Kieser for the information about the homologies of the mycobacterial sequence with the IS-like elements of Streptomyces and Rhizobium.

\section{References}

Cave, M. D., Eisenach, K. D., McDernott, P. F., Bates, J. H. \& CRAWFORD, J. T. (1991). IS6110: conservation of sequences in the Mycobacterium tuberculosis complex and its utilization in DNA fingerprinting. Molecular and Cellular Probes 5, 73-80.

Chen, C. W., Yu, T.-W., Chung, H.-M. \& Chou, C.-F. (1992). Discovery and characterization of a new transposable element, Tn4811, Streptomyces lividans 66. Journal of Bacteriology 174, 7762-7769.

Cirillo, J. F., Barletta, R. G., Bloom, B. R. \& Jacobs, W. R., JR (1991). A novel transposon trap for mycobacteria: isolation and characterization of IS1096. Journal of Bacteriology 173, 7772-7780.

Clark-Curtiss, J. E. \& Docherty, M. A. (1989). A species-specific repetitive sequence in Mycobacterium leprae DNA. Journal of Infectious Diseases 159, 7-15.

de Meirsman, C., Van Soom, C., Verreth, C., Van Gool, A. \& VANDERLEYDEN, J. (1990). Nucleotide sequence analysis of IS427 and its target sites in Agrobacterium tumefaciens T37. Plasmid 24, 227-234.

DevereuX, J., Haeberli, P. \& Smithies, O. (1984). A comprehensive set of sequence analysis programs for the VAX. Nucleic Acids Research 12, 387-395.

EisenaCh, K. D., CAVE, M. D., Bates, J. H. \& Crawford, J. T. (1990). Polymerase Chain reaction amplification of a repetitive DNA sequence specific for Mycobacterium tuberculosis. Journal of Infectious Diseases 161, 977-981.

van Embden, J. D. A., Cave, M. D., Crawford, J. T., Dale, J. W.,
Eisenach, K. D., Gicquel, B., Hermans, P., Martin, C., McAdam, R., SHINNICK, T. M. \& SMALl, P. M. (1993). Strain identification of Mycobacterium tuberculosis by DNA fingerprinting: Recommendations for a standardized methology. Journal of Clinical Microbiology 31, 406-409.

Ferrante, A. A. \& LeSSIE, R. G. (1991). Nucleotide sequence of IS402 from Pseudomonas cepacia. Gene 102, 143-144.

GoRMLEY, E. P. \& DAVIES, J. (1991). Transfer of plasmid RSF1010 by conjugation from Escherichia coli to Streptomyces lividans and Mycobacterium smegmatis. Journal of Bacteriology 173, 6705-6708.

Green, E. P., Tizard, M. L., Thompson, J., Winterbourne, J. D., MCFADDEN, J. J. \& Hermon-TAYLOR, J. (1989). Sequence and characteristics of IS 900 , an insertion element identified in a human Crohn's disease isolate of Mycobacterium paratuberculosis. Nucleic Acids Research 17, 9063-9073.

Grosskinsky, C. M., Jacobs, W. R., JR, Clark-Curtiss, J. E. \& Bloom, B. R. (1989). Genetic relationships among Mycobacterium leprae, Mycobacterium tuberculosis, and candidate leprosy vaccine strains determined by DNA hybridization: identification of an $M$. leprae-specific repetitive sequence. Infection and Immunity 57, $1535-1541$.

Hoover, T. A., Vodkin, M. H. \& Williams, J. C. (1992). A Coxiella burnetii repeated DNA element resembling a bacterial insertion sequence. Journal of Bacteriology 174, 5540-5548.

IIDA, S., MeYER, J. \& ARBER, W. (1983). Prokaryotic IS elements. In Mobile Genetic Elements, pp. 159-221. Edited by J. A. Shapiro. New York: Academic Press.

Kuehn, M., Lent, K., HaAs, J., Hagenzieker, J., Cervin, M. \& Smith, A. L. (1992). Fimbriation of Pseudomonas cepacia. Infection and Immunity 60, 2002-2007.

Kunze, Z. M., Wall, S., Appelberg, R., Silva, M. T., Portaels, F. \& MCFADDEN, J. J. (1991). IS901, a new member of a widespread class of atypical insertion sequences, is associated with pathogenicity in Mycobacterium avium. Molecular Microbiology 5, 2265-2272.

Maniatis, T., Fritsch, E. F. \& Sambrook, J. (1982). Molecular Cloning. A Laboratory Manual. Cold Spring Harbor, NY: Cold Spring Harbor Laboratory.

Martin, C., Timm, J., Rauzier, J., Gomez-Lus, R., Davies, J. \& GICQUEL, B. (1990). Transposition of an antibiotic resistance element in mycobacteria. Nature, London 345, 739-743.

McAdam, R. A., Hermans, P. W. M., van SoOlingen, D., Zainuddin, Z. F., Catty, D., van Embden, J. D. A. \& Dale, J. W. (1990). Characterization of a Mycobacterium tuberculosis insertion sequence belonging to the IS3 family. Molecular Microbiology 4, 1607-1613.

MCFAdDEN, J. J., ButCher, P. D., ChIOdini, R. \& Hermon-TAYloR, J. (1987). Crohn's disease-isolated mycobacteria are identical to Mycobacterium paratuberculosis, as determined by DNA probes that distinguish between mycobacterial species. Journal of Clinical Microbiology 25, 796-801.

Moss, M. T., Malik, Z. P., Tizard, M. L., Green, E. P., Sanderson, E. D. \& HeRMON-TAYLOR, J. (1992). IS902, an insertion element of the chronic-enteritis-causing Mycobacterium avium subsp. silvaticum. Journal of General Microbiology 138, 139-145.

Patel, R. J., Fries, J. W. U., Piessens, W. F. \& Wirth, D. F. (1990). Sequence analysis and amplification by polymerase chain reaction of a cloned DNA fragment for identification of Mycobacterium tuberculosis. Journal of Clinical Microbiology 28, 513-518.

Paulus, I., Canady, J., Vincent, F., Bonnard, G., Kares, C. \& OtTEN, L. (1991). Sequence of the iaa and ipt region of different Agrobacterium tumefaciens biotype III octopine strains: reconstruction of octopine Ti plasmid evolution. Plant Molecular Biology 16, 601-614.

Rappuoli, R. \& GRoss, R. (1990). att sites, tox gene and insertion elements as tools for the diagnosis and molecular epidemiology of Corynebacterium diphtheriae. In Gene Probes for Bacteria, pp. 205-232. Edited by A. J. L. Macario \& E. Conway de Macario. New York: Academic Press.

RuNYON, E. H. (1959). Anonymous mycobacteria in pulmonary disease. Medical Journal of Northern America 43, 273-290.

SCORDILIS, G. E., ReE, H. \& Lessie, T. G. (1987). Identification of transposable elements which activate gene expression in Pseudomonas cepacia. Journal of Bacteriology 169, 8-13. 
Soto, M. J., Zarzano, A., Olivares, J. \& Toro, N. (1992). Unpublished sequence. GenEMBL accession number X65471.

Thierry, D., Brisson-Noel, A., Levy-Frebault, V., Nguyen, S., GuesDON, J. \& GiCQUEL, B. (1990). Characterization of a Mycobacterium tuberculosis insertion sequence, IS6110, and its application in diagnosis. Journal of Clinical Microbiology 28, 2668-2673.

Vanderleyden, J., Desair, J., De Meirsman, C., Michiels, K., Van Gool, A. P., Chilton, M. D. \& JEN, G. C. (1986). Nucleotide sequence of an insertion sequence element of the Ti-plasmid Ti37. Nucleic Acids Research 14, 6699-6709.

Vismara, D., Filippone Mezzopreti, M., Gilardini, M., Del Porto, P., Lombardi, G., Piccolella, E., Damiani, G., Rappuoli, R. \& ColizzI, V. (1990). Identification of a 35-Kilodalton Mycobacterium tuberculosis protein containing B- and T-cell epitopes. Infection and Immunity 58, 245-251.

Woods, S. A. \& Cole, S. T. (1990). A family of dispersed repeats in Mycobacterium leprae. Molecular Microbiology 4, 1745-1751. 